\title{
Introduktion til Det kongelige Biblioteks arkiv
}

af seniorforsker Harald Ilsøe

Håndskriftafdelingen udgiver ved årsskiftet en trykt registratur over bibliotekets arkiv, hvis indhold kan benyttes på samme måde som håndskriftsamlingen. Arkivet går tilbage til Frederik IIIs tid og rummer meget upåagtet kildemateriale til dansk bog-og bibliotekshistorie frem til ca. 1950. I anledning af udgivelsen gengives her registraturens indledende præsentation af arkivet og dets historie.

Det kongelige Bibliotek har som institution bestået siden Frederik IIIs tid (164870), og lige så gammelt er dets arkiv. Det har naturligvis været flittigt benyttet af bibliotekets historikere gennem tiderne, frem for alt af E.C. Werlauff ved udarbejdelsen af hans grundige bibliotekshistorie fra 1844, og det har ligeledes været en vigtig kilde til de trykte håndskriftkatalogers oplysninger om de enkelte håndskrifters proveniens. Men forskningsmulighederne er langt fra udtømt, og når disse i mindre grad har tiltrukket et publikum uden for biblioteket, bærer biblioteket sin del af skylden. Selv om arkivet længe har været tilgængeligt via en håndskrevet registratur i Håndskriftafdelingen, har der hidtil ikke ligefrem været gjort reklame for dets benyttelse. Undertegnede husker, hvordan jeg i begyndelsen af 1960erne brugte megen tid på at finde en fortegnelse over historikeren Hans Grams håndskriftsamling, som der gentagne gange blev henvist til i den trykte katalog over bibliotekets latinske middelalderhåndskrifter. Den indgik ikke i den trykte auktionskatalog over hans bibliotek, og jeg kunne heller ikke finde den i Håndskriftsamlingen. Hvor var den blevet af? Det var nærmest et tilfælde der omsider sporede undersøgelsen ind på arkivet og en heraf følgende anmodning om at få en registratur at se på katalogværelset. Dér blev fortegnelsen så fundet under E 41 som et aktstykke vedrørende bibliotekets køb af samlingen. Jeg lærte ved den lejlighed, at arkivet rummer en række gamle 
kataloger og delfortegnelser over privatbiblioteker, der er erhvervet til biblioteket. Som specifikationer af de modtagne samlinger udgjorde de en dokumentation af den pågældende tilvækst og fungerede samtidig som midlertidige kataloger, indtil samlingerne var indlemmet i hovedsamlingen. Deres hjemsted er helt regulært arkivet - men det er altså lige det med at vide det.

Arkivet beretter derfor ikke blot om institutionen Det kongelige Biblioteks historie, men bidrager gennem de mange registrerede erhvervelser af bøger og håndskrifter også væsentligt til anden dansk og udenlandsk bibliotekshistorie fra 1600tallet og fremefter. Brugere af den nu trykte registratur bør her som i andre tilfælde gøre sig klart, at et emne ofte findes belyst i flere af arkivets grupper. Bibliotekets erhvervelser belyses f.eks. både af gruppe E med de forskellige håndskrevne kataloger, gruppe A med korrespondancer og journalsager, gruppe B med regnskaber og gruppe F med "Tilvæxt". Giver man sig lidt tid til at gennemse registraturen, vil det yderligere fremgå, at arkivet er en vigtig kilde til dansk bogvæsen overhovedet. Pligtafleveringsprotokollerne, der er bevaret siden 1778 , rummer årlige fortegnelser over bogtrykkernes lovbefalede afleveringer til biblioteket af deres trykproduktion og er dermed en hovedkilde til den danske trykproduktions historie (E 39, F 1 og F 42ff). Boghandler- og auktionsregninger belyser boghandlens historie tilbage til 1750erne (E 39-40 og gruppe F), og fra et senere tidspunkt kan bogbinderregninger og indbindingsprotokoller danne udgangspunkt for studier i dansk bogbindshistorie (især gruppe G). Og så skal det ikke overses, at også bibliotekets benyttelse har afsat sig mange spor. F. eks. giver udlånsprotokoller værdifulde oplysninger om læsningens og forskningens historie ved at fortælle, hvem og hvor mange der til forskellige tider har benyttet hvilke bøger. De er bevaret fra 1778 i D 5, fuldstændigt dog først fra 1809.

Uden af foregribe mulighederne kan nogle eksempler på forskningsmæssig udnyttelse af arkivet måske inspirere til efterfølgelse: Carl S. Petersen har med benyttelse af katalogen i E 2 skrevet en lødig studie over rigshofmester Joachim Gersdorffs store bibliotek fra midten af 1600tallet (Afhandlinger, 1949, s. 116-76), mens Ada Adler til dels på grundlag af biblioteksarkivalier i en lærd disputats har skildret D.G. Moldenhawer som international håndskriftsamler sidst i 1700 tallet. Fra tilvækstprotokollerne har E. Gigas meddelt oplysninger om auktionspriser på bøger og håndskrifter i 1780erne (Bogvennen 1895, s. 35-37), og med støtte i en af bogbinderprotokollerne har Carl Roos fortalt om August Sandgren og hans virksomhed for biblioteket 1924ff (i Bogbinderen August Sandgren, 1952, s. 50-60). Pligtafleveringsprotokollerne er f.eks. blevet udnyttet i statistisk og anden sammenhæng af Erik Dal (Dansk Provinstryk gennem 500 år, 
1982) og for de københavnske bogtrykkeres vedkommende i årene 1790-1809 af Harald Ilsøe (Bogtrykkerne i København og deres virksomhed ca. 1600-1810, 1992, s. 247-52). Bogbenyttelsen som den afspejler sig i udlån og brugerkreds i årtierne omkring 1800 har Christian Kaatmann undersøgt i Fund og Forskning 33, 1994, og konkret har f.eks. Carl S. Petersen i udlånsprotokollerne fundet vidnesbyrd om Oehlenschlägers studier i de år, han skrev sine ungdomsværker (Afhandlinger s. 284-86), ligesom Henning Fenger fra samme kilde har fremdraget oplysninger om Georg Brandes' læsning halvtreds år senere (Georg Brandes' læreår, 1955, s. 439-60).

\section{Lidt om arkivets historie og overlevering}

Ved benyttelsen af et arkiv kan det være nyttigt eller tilmed nødvendigt at skaffe sig indblik i dets tilblivelse og historie samt at vurdere, i hvilket omfang det er overleveret. Herom skal der følgelig gøres nogle bemærkninger, omend de må blive af foreløbig karakter, da disse spørgsmål ikke foreligger grundigt undersøgt.

Af ældre registraturer findes der i E 57 en fortegnelse fra 1780erne over bibliotekets "Inventaria", dvs. en oversigt udarbejdet af Jon Erichsen over de i hans bibliotekartid (1781-87) eksisterende utrykte kataloger. Den svarer nogenlunde til den nuværende arkivgruppe E nr. 1-63. En mere omfattende registratur blev vistnok først udarbejdet $\mathrm{i}$ årene omkring 1880, da historikeren C.F. Bricka som bibliotekets medarbejder i Håndskriftsamlingen registrerede journalsagernes ældste række frem til 1861 (jvf. A 1). Som arkivet voksede blev registraturen àjourført for så i 1942 at blive redigeret i sin nuværende form, efter at der var blevet foretaget en revision, som bl.a. medførte overførsler af enkelte håndskrifter fra arkivet til Håndskriftsamlingen. Det var året før Carl S. Petersens afgang som overbibliotekar og er formentlig sket på hans initiativ. I de umiddelbart foregående år havde han selv gjort flittig brug af arkivet med henblik på sin fremstilling af Håndskriftsamlingens historie (trykt i Bogens Verden 1942, udgivet som selvstændig publikation 1943).

Historisk kan der af flere grunde sættes skel ved 1778. I dette år begyndte J.H. Schlegel at reorganisere biblioteket, efter at dets administration var gået i forfald under Bernhard Møllmanns ledelse (1748-78). Samtidig blev der under stilfærdige former åbnet adgang for et kvalificeret publikum og femten år senere for fuld udblæsning for almenheden. Reorganiseringen af bl.a. bogtrykkernes pligtaflevering, administrationen af udlån til publikum, indlemmelsen af store erhvervelser gennem 1780erne og -90erne og iværksættelse af katalogiseringsarbejder bevirkede et stærkt forøget administrativt apparat, der kan aflæses af arkivet og dets efterhånden voksende forgreninger. 


$$
\begin{aligned}
& \text { P. }, 2
\end{aligned}
$$

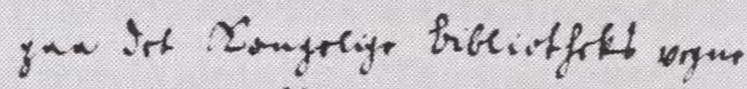

$$
\begin{aligned}
& \text { he bogrogthmer i Disingforw }
\end{aligned}
$$

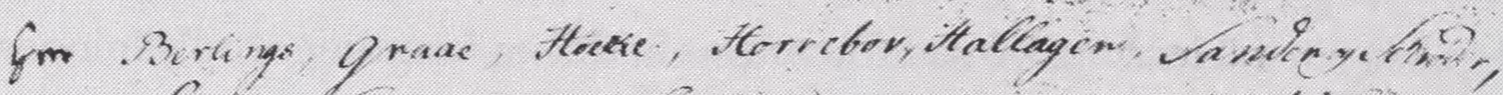

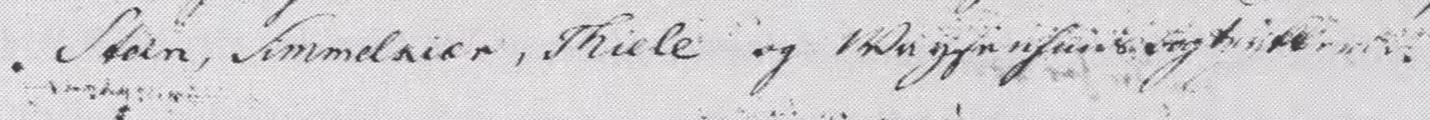

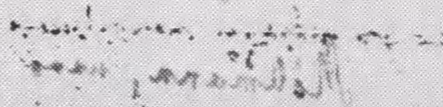

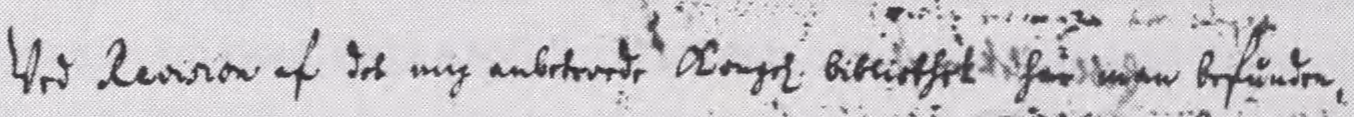

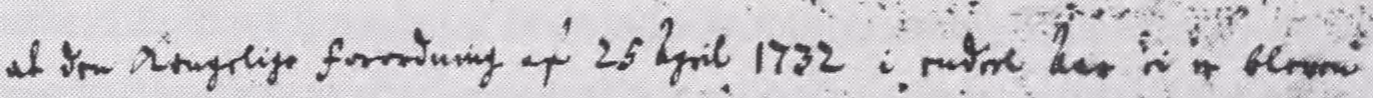

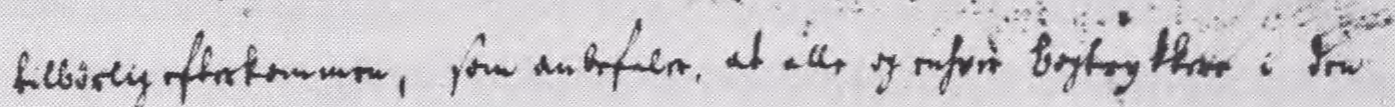

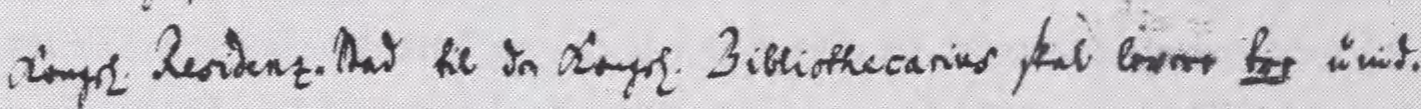

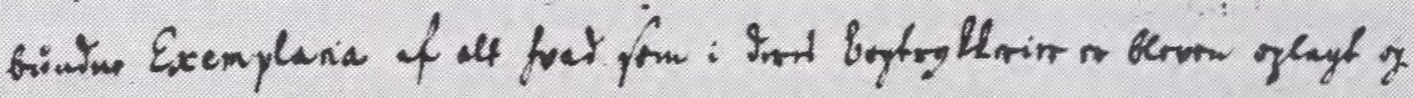

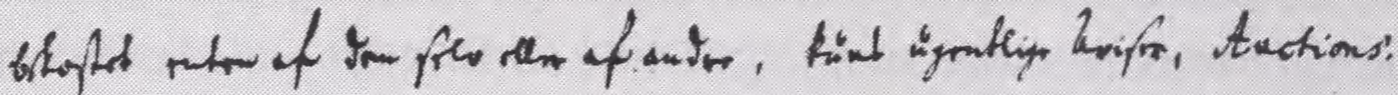

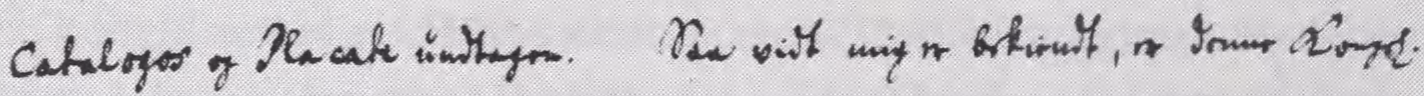

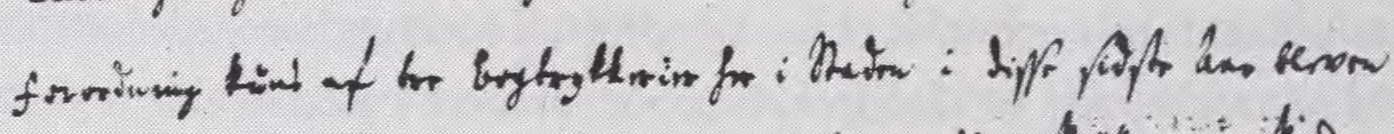

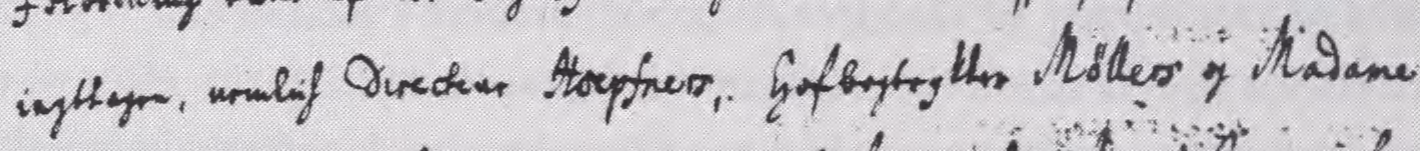

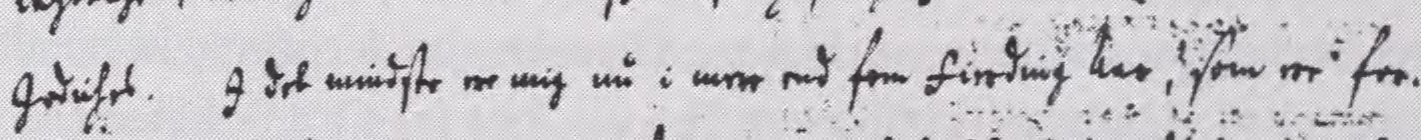

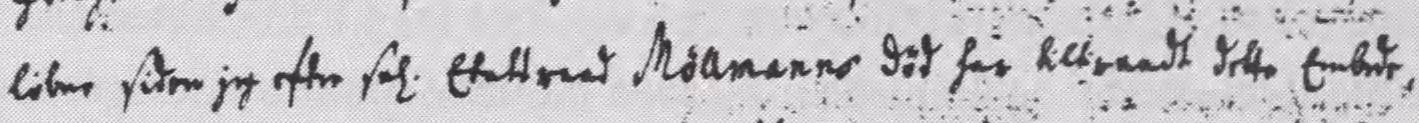

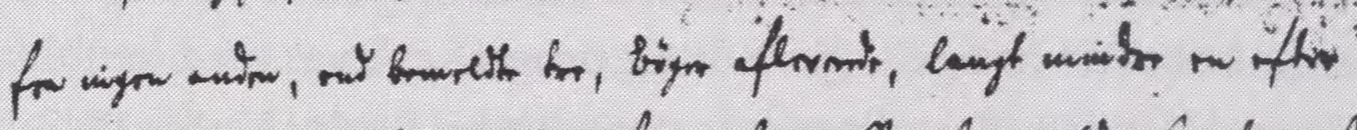

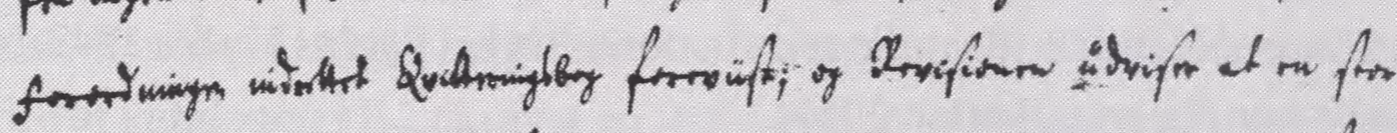

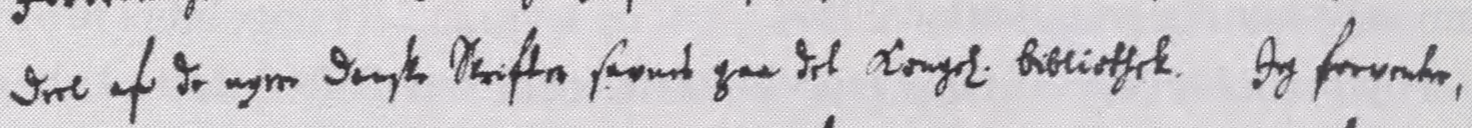

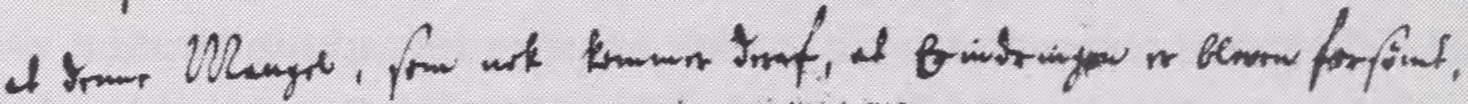

Det har gennem små 300 år været en vigtig opgave for Det kongelige Bibliotek at sikre, at et eksemplar af al trykt litteratur i Danmark bliver afleveret til opbevaring i biblioteket. Dette sker gennem en lovpligtig aflevering fra bogtrykkerne, men da biblioteket under Bernhard Møllmanns ledelse (1748-78) forsømte tilsynet hermed, gik afleveringerne i 


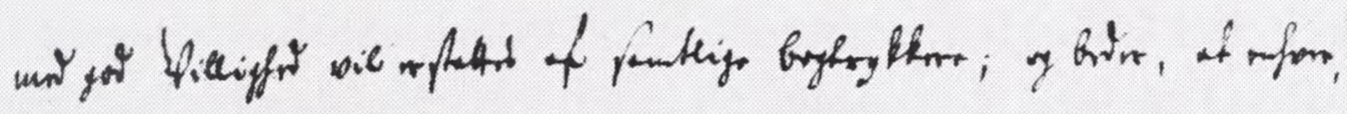

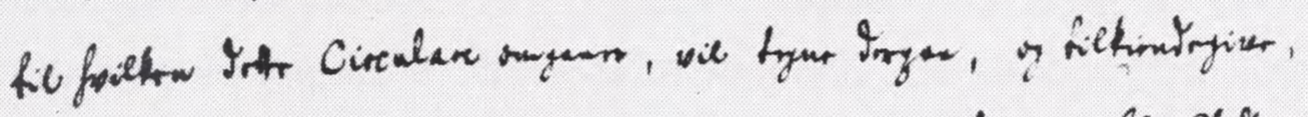

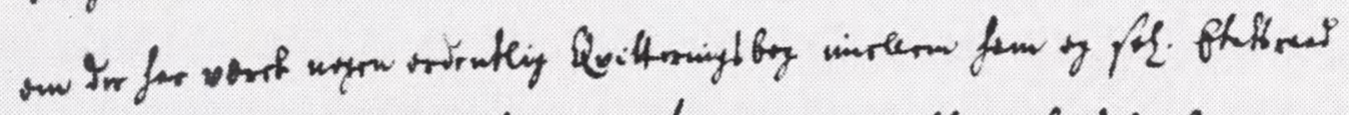

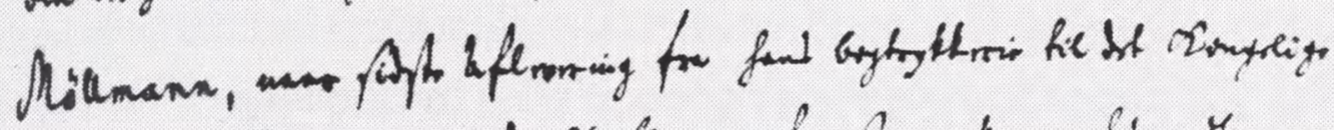

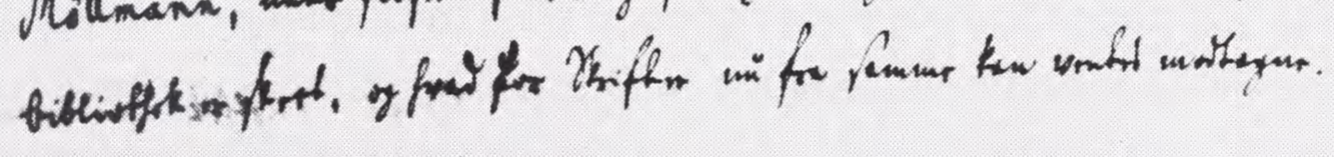
Dithluow tow 23 Yes. 1779. St......... Histing Bohama theinnich Schlegid.

jomaing Graac tormanit Aföecke.

corrmingt Thiele.

fintin, Stallayer

Sarmint climelkion.

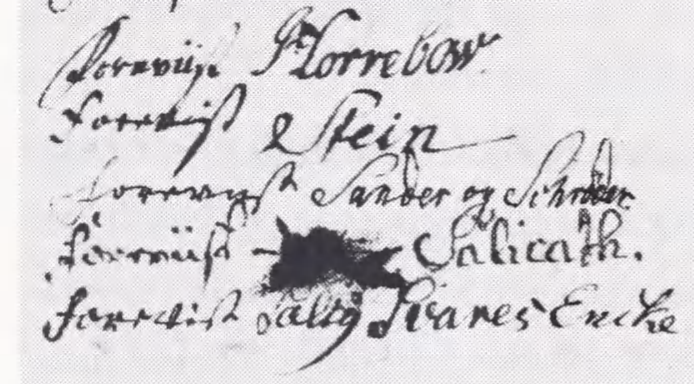

stå, så efterfølgeren J.H. Schlegel måtte indhente det forsømte. Her gengives et aktstykke fra 1779 , hvor samtlige hovedstadens bogtrykkere har måttet skrive under på, at de ville overholde pligtafleveringsforordningen af 25. april 1732. - KBs arkiv, A 8: Journalsag nr. 112.

17 
Anderledes før 1778. Indtil oprettelsen af Det kongelige Håndbibliotek ca. 1750 havde lederen af Det kongelige Bibliotek status som kongens private bibliotekar, der passede stillingen som et bijob ved siden af anden stilling, og personalet bestod derudover kun af et par studentermedhjælpere. Ordrerne fra kongen var ikke sjældent mundtlige, og arbejdet bestod hovedsagelig $i$ at fremkomme med forslag til køb samt at modtage og opstille bøgerne. Regnskabsaflæggelse foregik ved, at de af bibliotekaren attesterede regninger blev sendt til udbetaling fra kongens kasse under det såkaldte Partikulærkammer. Udlån fandt næsten ikke sted til andre end medlemmer af kongefamilien, så administrationen heraf kunne klares med nogle seddelnotitser eller indførsler i en notesbog (jvf. D 4). Administrationen var følgelig minimal, og omfanget af journalsagerne begynder da også først rigtig at vokse fra ca. 1750, da den personlige adgang til kongen var under afvikling. Hertil kommer, at de ikke mange skriftlige forespørgsler vedrørende bøger og håndskrifter ofte blev besvaret i privatbreve, hvorfor man f.eks. fra Hans Grams bibliotekartid (1730-48) finder noget der ligner korrespondancesager mellem hans privatpapirer i Håndskriftsamlingen. Andre 'sager' fra 1700tallet kan man være så heldig at finde bedre belyst $i$ centraladministrationens arkiver i Rigsarkivet eller i samlinger tilvejebragt af privatsamlere. Således stammer en fyldig korrespondance fra 1762 med forespørgsler og besvarelser om tilstedeværelsen af gamle irske håndskrifter i Det kongelige Bibliotek, nu NkS 746 fol., fra bogsamleren B.W. Luxdorphs manuskriptsamling.

Hovedafkastet af bibliotekarens administration før 1778 er rækken af bogog håndskriftkataloger i gruppe $\mathrm{E}$, dels bestående af fortegnelser og kataloger over erhvervede privatsamlinger, dels af kataloger over bibliotekets hovedsamling, hvori disse efterhånden blev indordnet. Bibliotekarerne skulle stå inde for, at der ikke skete svind i bestanden, og derfor blev der i princippet ved bibliotekarskifterne frem til 1778 udarbejdet reviderede kataloger over bestanden, som den tiltrædende bibliotekar så fik i sin varetægt og var ansvarlig for (se f.eks. E 6). Dog kun i princippet, for overleveringsforretningerne blev ikke altid regelret gennemført, men takket være dem, der blev det, er der bevaret kataloger over bestanden til forskellige tider, som er af stor interesse for bibliotekets historie frem til 1778/1780, da den sidste overleveringsforretning fandt sted.

Omtalte Møllmann var ingen ven af administrativt arbejde og snød sig fra at affatte en katalog ved sin tiltrædelse i 1748. Helt galt gik det i hans embedstid, hvor han forsømte at katalogisere tilvæksten, og ved hans død 1778 blev der forefundet så vild en uorden i biblioteket, at der måtte nedsættes en kommission til at få skik på sagerne. Det store revisionsarbejde med at nyregistrere 
bestanden tog flere år og resulterede i adskillige fortegnelser og katalogarbejder (E 36, E 38, E 40-41 og E 43-47 samt en arbejdsprotokol i journalsag nr. 155b). Da kommissionen for at rekonstruere tilvæksten i Møllmanns tid måtte låne samtlige bilag til auktions- og boghandlerkøbene samt bogbinderregningerne fra Partikulærkassens arkiv, finder man disse afskrevet i E 40. Værre var dog, at Møllmann havde lånt en mængde håndskrifter hjem, og da han også havde lånt håndskrifter fra både Universitetsbiblioteket og Den Arnamagnæanske Samling og desuden selv efterlod sig en håndskriftsamling, måtte kommissionen stykke for stykke tage stilling til, hvilke håndskrifter der hørte hjemme hvor. Derved blev bl.a. "et temmeligt Antal af Manuskripter" ført tilbage til Universitetsbiblioteket (Mindeskrift for Oluf Borch ved Vilhelm Maar, 1926, s. 114), men sorteringen foregik næppe uden enkelte fejlskøn, og usandsynligt er det vel heller ikke, at et og andet er bortkommet i det tredive år gamle rod.

Det er så heldigt, at der findes en fortegnelse over arkivet, før det kom i hænderne på Møllmann. I den store bestandskatalog i fire bind, der blev udarbejdet i 1730 i anledning af J.C. Wolfens afgang som bibliotekar (E 20), registreres hen mod slutningen, hvad der fandtes "udi Kammeret uden for Bibliothequet", dvs. i et rum hvor bibliotekaren kunne sidde og arbejde. Stukket ind mellem andre håndskrifter anføres umiddelbart efter hinanden 16 titler, der til dels genkendes fra den nuværende arkivgruppe E. At de har været placeret der som arbejdsredskaber for Wolfen underbygges af den omstændighed, at der lige efter følger et ufærdigt manuskript, betegnet som "En tydsk Version af et scripto-alchymico af Sl. EtatsR. Wolfen giort paa Kongl. Ordre, incompl. fol.".

Den lille arkivfortegnelse, vistnok den ældste bevarede, har interesse af flere grunde. Titlerne gengives her fra E 20 vol. 4 s. $712 \mathrm{f}$ med tilføjet nummerering og identifikation, hvor det er muligt:

1 En begynt Catalogus over K: Bibliothec med deri begynde 4 Chartequer af Marc Meibomii haand. fol. blaat Papier (Marcus Meibom var bibliotekets første bibliotekar)

2 Catalogus Libror. Jurid. medic. \& historic. Bibliothecæ Hermanni Mejeri. 1673 (= E 12, katalog over Herman Mejers bibliotek erhvervet 1673)

3 Catalogus Bibliothecæ Regiæ prout a M. Meibomio tradita est P. Schumachero 1663 \& deinde Wilhelm. Wormio 1671. Deri ligger: Enumeratio Librorum Bibliothecæ Friderici III. fol. tyrkisk Papiir. it<em> Index Auctorum Biblioth. Ulfeldii 4to (= henholdsvis E 6, E 4 og NkS 1259 c 4to, sidstnævnte skrevet i 1600tallet og med titlen: IndexAutorum Bibliothecæ Laurentij Ulfeldij) 
4 Catalogus alphabeticus Biblioth. Regiæ inceptus, volum. spissum fol. (=E 1)

5 Catalogus Librorum viri cuj<usdam > Illustris publica Auctione vendendorum. Hamb. 1690. fol. løse blade (= GkS 479 fol., med titlen: Catalogus Selectiorum Librorum ... a Viro quodam Illustri p.m. comparatorum. Quorum Auctio Deo volente habebitur die 30. Septembris et seqq. Hamburgi Anno MDCXC. Bladene er indsat $\mathrm{i}$ et papbind i dette århundrede. Kan identificeres som en afskrift af (eller manuskriptet til?) den trykte auktionskatalog over Esaias Pufendorfs bibliotek, der blev købt til Kgl. Bibl. 1690. Katalogen efterfølges af en manuskriptkatalog, som ikke synes at have noget med Pufendorfs bibliotek at gøre)

6 Et stort Convolut af Catalogis over det Kongel. Biblioth. af Sl. Wilhelmi Wormii haand (=E 9)

7 En anden Packe, adskillige Kladder og Stumper af begyndte Catalogis i Sl. EtatsRaad Wolfens Tiid, med nogle deri liggende ældre Chartequer

8 Catalogus Biblioth. Reitzerianæ, 3 store Volumina paa regal Papiir (Katalog over Chr. Reitzers bibliotek købt 1721. Se nedenfor)

9 Catalogus over de fra Güstrow kommne bøger. fol. (= E 16)

10 Catalogus over hoysalig Dronning Louises bøger. 4to (= $E 17$ eller $E 18$, kataloger over bogsamlingen efterladt af dronningen 1721)

11 Designatio Librorum P. Scavenii. Hafn. 1660. 4to trykt (Katalog over biblioteket, som blev købt af Frederik III, se Danske Afdeling)

12 Designatio Librorum Laurent. Ulfeldii. 4to. 1662 (Trykt katalog over biblioteket, som blev købt af Frederik III, se Danske Afdeling)

13 Designatio Librorum Dn. Ahasveri Paynek 4to skreven, Bibl. Regiæ accesserunt (Bøger og håndskrifter fra Ahasverus Payngks bo blev købt ca. 1667-69. Tabt).

14 En skreven Catalogus over bøger og Mathematiske Instrumenter, hvori ligger 2 Designationer af Walgensteins Instrumenta mathematica (Samlingen købt af Christian V 1682. Tabt)

15 Catalogus Bibliothecæ Rostgardianæ i 2 Engelske bind. 8vo (Den i 1726 trykte auktionskatalog over Fr. Rostgaards bibliotek, hvor der blev købt nogle få håndskrifter til biblioteket, se Danske Afdeling)

1612 Exemplaria af en Auctions-Catalogo ... 1723. 8vo (Trykt auktionskatalog over bibliotekets dubletter, se Danske Afdeling).

Katalogen over Joachim Gersdorffs bibliotek (nuværende E 2) må ligesom enkelte andre stykker have befundet sig andetsteds, men bortset herfra er der tydeligt 


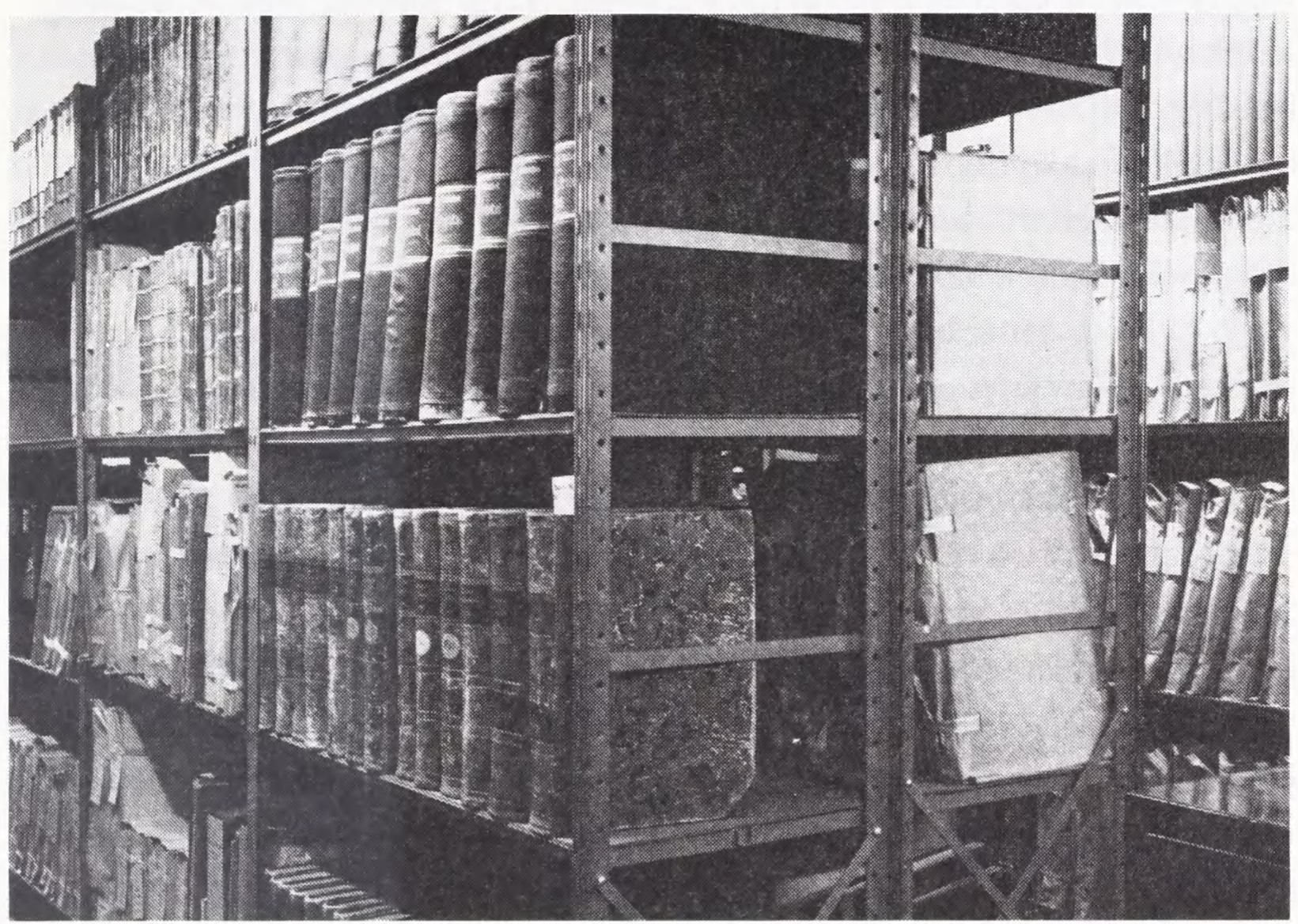

Det kongelige Bibliotek Slotsholmen. Her opbevares Det kongelige Biblioteks arkiv. Fot. Erik Jul.

tale om en bestand af kataloger over biblioteket fra Frederik IIIs tid frem til 1720rne. Det ses, at den rimeligt nok omfattede de trykte kataloger over Scavenius' og Ulfeldts biblioteker (nr. 11-12), som repræsenterede en accession fra Frederik IIIs tid. De er senere blevet afgivet til Danske Afdelings bogsamling, ligesom de trykte kataloger over frasalget i 1723 (nr. 16) er blevet udskilt. En lignende skæbne har et par håndskrevne kataloger fået. Nr. 5, katalogen over Esaias Pufendorfs bibliotek, der blev købt 1690, findes nu i Håndskriftsamlingen, hvortil den må være overført senest i begyndelsen af 1780erne, hvor bibliotekets håndskrifter blev indordnet i "Gl. kgl. Samling" (GkS). Derimod er forfatterregisteret til Uldfeldts bøger i nr. 3 først blevet overført til Håndskriftsamlingen engang i 1800tallet, efter at samlingen med signaturen "Ny kgl. Samling" (NkS) var oprettet, og man har da begået den undladelsessynd ikke at notere proveniensen (jvf. E. Gigas: Katalog II (1906) s. 80).

Hvorfor disse overførsler er blevet sat i værk, kan der kun gisnes om, men for Pufendorf-katalogens vedkommende skyldes det formodentlig, at man under oprydningen efter Møllmann har haft vanskeligt ved at bestemme dens indhold 
og proveniens og derfor tyede til at indlemme den som en anonym auktionskatalog i Håndskriftsamlingen. Som sådan har den stået registreret og antagelig ubenyttet til den dag i dag. Der er imidlertid god grund til at anse den for bibliotekarens oprindelige håndeksemplar og dermed hørende til arkivet, ikke mindst fordi den indeholder et tillæg med uindbundne bøger, som ikke findes i de to eksemplarer, biblioteket ejer af trykudgaven.

Endvidere fremgår det, at to fortegnelser efter alt at dømme er gået tabt, de eneste der havde kunne oplyse, hvad der indgik i biblioteket fra henholdsvis lægen Ahasverus Payngks og fysikeren Thomas Walgenstens samlinger (nr. 13 og 14). Da de ikke findes i Jon Erichsens fortegnelse fra 1780erne (E 57), er de sandsynligvis forsvundet i Møllmanns tid. I Werlauffs bibliotekshistorie er de to erhvervelser overhovedet ikke nævnt.

Størst besvær har det voldt at identificere katalogen over Christian Reitzers bibliotek i nr. 8 , for hverken arkivet eller Håndskriftsamlingen rummer angiveligt en sådan katalog. Men tre store bind "paa regal Papiir" - altså i stort folioformat - kan jo vanskelig tænkes sporløst forsvundet, og det er de heller ikke. De anføres atter i Erichsens fortegnelse, og ved en nærmere undersøgelse af E 15, der i arkivregistraturen betegnes som en "Generalkatalog over bogbestanden", viser det sig, at denne katalog fra 1729 må være identisk med netop "Catalogus Bibliothecæ Reitzerianæ". Når dette har kunnet gå i glemmebogen, skyldes det, at de tre bind i E 15 er uden titel. Men de er ganske rigtig meget store, og katalogens indhold på omkring 15.-16.000 bind stemmer fortrinlig overens med oplysninger fra anden side om størrelsen af Reitzers bibliotek i 1718, da kongen fik tilbud om at købe det. Forhandlingerne trak ud i tre år, så da Frederik IV endelig slog til, var det vokset med endnu et par tusinde bind! Identificeringen dokumenteres ved et par stikprøver. Ifølge et notat af Fr. Rostgaard om sjældne bøger i Reitzers bibliotek (i NkS 380 fol.) ejede han bl.a. "Die Cronica van der hilliger Stat Coellen". Denne udgave fra 1499 anføres i E 15 (vol. 1 s. 94/95), hvor den ligeledes betegnes som sjælden. Desuden er det kendt, at Reitzer ved arv var kommet i besiddelse af historikeren Otto Sperlings store håndskrevne samlinger, og eksempler på sådanne Sperlingiana findes i E 15 i så rigt et mål, at enhver tvivl om katalogens identitet må forstumme (se f. eks. vol. 1 s. 518/19 og vol. 2 s. 312/13).

E 15 (med Reitzers bibliotek) hører simpelthen sammen med E 20 (katalog over bibliotekets ældre og øvrige bestand), idet katalogerne sammen med katalogen over det af dronning Louises efterladte bibliotek (ovenfor nr. 10) er led i den revisionsforretning, der blev foretaget over hele Det kongelige Biblioteks bestand 1729-30, inden den ved Wolfens afgang som bibliotekar skulle overleveres til ef- 
terfølgeren. Forbindelsen godtgøres yderligere af, at efterslættet fra Reitzers bibliotek bestående af uindbundne bøger og nogle håndskrifter, som ikke var kommet med i Reitzer-katalogen, findes indført i E 20 (se f. eks. vol. 2 s. $575 \mathrm{ff}$ og $584 \mathrm{ff})$.

Til bestanden hørte også en stor samling kobberstik, hvorover der anføres fortegnelser både i E 20 (vol. 4 s. 681ff) og E 57. Når de ikke længere befinder sig i arkivet, er grunden, at de fulgte med kobberstikkene ved overførslen til den i 1835 oprettede institution Den kongelige Kobberstiksamling (jvf. Emil Bloch: Den kgl. Kobberstiksamling, 1881, s. 2-4).

Mens således noget er gået tabt eller overført til andre samlinger i og uden for biblioteket, er arkivet på den anden side blevet forøget ved, at der lejlighedvis er puttet noget ind, som man med større eller mindre ret har ment hørte til det. E 6 a er fotostat af en dubletfortegnelse fra 1667, der opbevares i Rigsarkivet, mens E 13, der betegnes som en "Katalog, muligvis over Mogens Friis' bibliotek", er af ukendt proveniens. Den findes ikke i de nævnte arkivfortegnelser, og da Mogens Friis' bibliotek hørte blandt Det kongelige Biblioteks markante erhvervelser i sidste halvdel af 1600 tallet, havde Werlauff utvivlsomt omtalt katalogen i sin bibliotekshistorie, om han havde kendt den. Dvs. E 13 er efter alt at dømme anbragt i arkivet efter 1844 . Helt sikkert vides, at D 4 med nogle udlånsoptegnelser af Hans Gram først er indgået i biblioteket ca. 1890, og derudover bærer flere af de ældste journalsager i gruppe A umiskendelige spor af at være kommet til i et forsøg på at rekonstruere arkivet.

F. eks. består A 1 a af en afskrift af Frederik IIs udnævnelse af en bibliotekar i 1589, historisk interesssant, men dog næppe et aktstykke fra det af Frederik III grundlagte bibliotek. A 1 h er en samling breve om en planlagt udgave af bibliotekets Tycho Brahe-manuskripter i Paris. De er udtaget af Langebeks excerpter nr. 179, og det samme gælder A 7a-o, nogle aktstykker vedrørende købet af Christian Reitzers bibliotek, som er overført fra Langebeks excerpter nr. 184. Langebeks excerpter blev afleveret til biblioteket af Rigsarkivet i 1826. A 17-19 består af en afskrift og et par kladder af Arne Magnussons angående et køb på Fr. Rostgaards auktion i 1726 og stammer sandsynligvis fra Magnussons papirer i Den Arnamagnæanske Samling (se herom Arne Magnussons i AM. 435 A-B 4to indeholdte håndskriftfortegnelser, udg. ved Kr. Kålund 1909, s. ix-x med gengivelse af aktstykkerne s. xiii-xix). Og A 26 h, en boghandlerregning fra 1736, er som det ses af indførslen indlemmet i dette århundrede. Der er i sig selv ikke noget at udsætte på slige rekonstruktioner, men de bibringer unægtelig arkivets ældste bestand et præg af tilfældighed og rejser spørgsmålet, om der i så fald ikke 
burde være foretaget endnu nogle overførsler fra Håndskriftsamlingen. Der kan her nævnes Langebeks excerpter nr. 271, en "Fortegnelse paa de Manuscripter i det Kongelige Bibliothec, som henhøre til de danske jura", dvs. en tidlig katalog over bibliotekets danske lovhåndskrifter. Den er rimeligvis skrevet af Langebek, da han ca. 1735-48 var Hans Grams medhjælper på biblioteket, og kan dermed sidestilles med de andre gamle katalogarbejder i arkivet.

Hvad angår arkivets indhold efter 1778, må det anses for væsentligt bedre bevaret, skønt der findes nogle kedelige lakuner mellem ca. 1790 og 1815/1820. Pligtafleveringsprotokollerne er heldigvis til stede i ubrudt række, men der findes ingen tilvækstprotokol mellem 1789 og 1816 (F 2 / F 3), og specifikke fortegnelser over henholdsvis auktionskøb og gaver begynder først 1817 (F 18 og F 60). Fra samme tidsrum er journalpakkerne tynde sammenlignet med de følgende årtier, og slås der op i registeret til arkivregistrant A 1 under emnet årsberetninger, fremgår det, at disse nok er bevaret for årene 1780-86, men mangler fra 1787 til 1815. Helt god synes overleveringen først at blive fra og med E.C. Werlauffs tid (1823-61), og der står kun tilbage at gøre opmærksom på nogle smuthuller, der i påkommende tilfælde kan genere benyttelsen af arkivalierne i 1800tallet.

Siden Hans Grams og Jacob Langebeks dage har adskillige af bibliotekets bibliotekarer efterladt sig arkiver med papirer og breve, som er blevet indlemmet $i$ Håndskriftsamlingen, uagtet nogle af efterladenskaberne lige så godt eller snarere kunne opfattes som embedsarkivalier. Når undtages de omtalte småtterier fra Langebeks excerpter, har biblioteket som regel ikke lagt vægt på at udrede forholdet ved registreringen, og navnlig vistnok ikke, når papirerne er blevet modtaget eller registreret et større åremål efter ejerens død. Denne praksis har både fordele og ulemper, sidstnævnte naturligvis især for arkivbenyttelsen, da man undertiden må se sig henvist til at søge en sag oplyst - eller yderligere oplyst - blandt de private papirer i Håndskriftsamlingen. Her foreligger der navnlig muligheder i biblioteksledernes efterladenskaber - efter 1788: D.G. Moldenhawer (1788-1823), E.C. Werlauff (1823-61) J. Bølling (1861-62), Chr. Bruun (1862-1901) og H.O. Lange (1901-1924).

Mest typisk er der tale om korrespondancer, hvor private breve er blandet med biblioteksforespørgsler og -besvarelser. Det bedste eksempel frembyder den store samling breve fra Moldenhawers bo, som indgik ret sent $\mathrm{i}$ biblioteket og ikke blev ordnet førend i begyndelsen af 1900tallet. Samlingen findes i NkS 2396-97 4to og rummer talrige breve til Moldenhawer, der udelukkende omhandler biblioteksanliggender. De supplerer altså bibliotekets arkiv, så meget mere som der i arkivet findes andre breve fra samme afsendere. 
For sig selv står "Werlauffs Manuskripter", der er indgået efter Werlauffs død i 1871 og opbevares samlet under denne betegnelse i Håndskriftsamlingen. De rummer et meget broget materiale af alskens herkomst og repræsenterer både Werlauffs arkiv og en af ham tilvejebragt håndskriftsamling med brudstykker fra andre arkiver. Noget er senere blevet udtaget til Rigsarkivet, mens andet, som kunne have været overført til bibliotekets arkiv, er forblevet på sin plads. For blot at illustrere forholdet med et par stikprøver findes der i pakke 24 en officiel skrivelse fra Finanskollegiet til Moldenhawer i 1813 og i pakke 25 et brev fra Københavns magistrat i 1845 angående eftertryk af svenske bøger i Danmark, en udtalelse desangående af bibliotekaren i Danske Afdeling Fr. Fabricius samt Werlauffs koncept til et svar til magistraten. De tre sidstnævnte stykker udgør åbenbart en embedssag og har da heller ikke nogen modsvarighed i arkivets journalsager.

Ikke mindst har adskillige bibliotekarer gennem tiderne i forbindelse med deres arbejde og færden på biblioteket samlet notater eller opbygget kartoteker vedrørende bemærkelsesværdige tryk, håndskrifter, bind eller provenienser. Disse er gerne produkter af både deres tjenstlige arbejde og egne private undersøgelser og kan forsåvidt med lige så stor ret anses for at høre hjemme i arkivet som i Håndskriftsamlingen. Enkelte samlinger af den art findes faktisk i arkivet (se f.eks. E 74-77 og E 117), men hovedparten er modtaget som private efterladenskaber og er derfor placeret i Håndskriftsamlingen. Samlingerne findes følgelig registreret i den emneordnede skruebindskatalog på katalogværelset, hvor de fleste anføres i vol. 4 s. $167 \mathrm{ff}$ og vol. 7 s. 100, men de kan med større fordel søges under samlernes navne i den alfabetiske seddelkatalog, hvor oplysningerne som regel er mere fyldige. Relevante er formentlig først og fremmest samlinger anlagt af følgende forhenværende medarbejdere: W. Ahlefeldt-Laurvig, J. Bonnesen, Carl Elberling, H.O. Lange, Jacob Langebek, Victor Madsen, Carl Roos og E.C. Werlauff ("Werlauffs Manuskripter"; detaljeret registrering kun i E. Gigas: Katalog I (1903) s. 92-118). Arkivets indhold og fordeling kunne kommenteres ud fra andre synsvinkler, men ovenstående betragtninger og eksempler må være tilstrækkelige til at give arkivregistraturens brugere nogle vink om arkivets overlevering. Arkivet har meget at give, men da det i nogen grad bærer præg af at være opvokset med Håndskriftsamlingen som tvillingpartner, er det ikke sjældent tilrådeligt også at inddrage denne ved en arkivundersøgelse. Endelig har bibliotekets virksomhed jo også aflejret mangt og meget $\mathrm{i}$ kongens og centraladministrationens arkiver i Rigsarkivet, hvor der f.eks. må eksistere akter, der bidrager til at udfylde de nævnte lakuner i overleveringen af bibliotekets arkivalier fra 1790-1815/1820. 
Dette er selvsagt et andet spørgsmål, men det bør måske lige tilføjes, at biblioteket i de selvsamme år fik betydelige aktiviteter finansieret af en særlig fond, "Fonden ad usus publicos". De pågældende akter er publiceret eller refereret i: Fonden ad usus publicos. Aktmæssige bidrag til Belysning afdens Virksomhed udg. af Rigsarkivet, I (1765-1800) - II (1801-1826), 1897-1902, begge bind med register. 